\title{
THE EFFECT OF ARTIFICIAL VENTILATION ON FRC AND ARTERIAL OXYGENATION
}

\section{Rapid Shallow Ventilation at Normal and Low Arterial Carbon Dioxide TENSIONS*}

\author{
H.I.A. NISBET, M.B., CH.B., F.F.A.R.C.S.(ENG.), F.R.C.P.(C), \\ T.L. DobBINSON, M.B., C.H.B., F.F.A.R.A.C.S., \\ D.J. STEWARD, M.B., B.S.(LOND.), F.R.C.P.(C), AND G.A. VolgYeSI, P.ENG.
}

\section{INTRODUCTION}

FunCtIonal RESIDUAL CAPACITY (FRC) is reduced during anaesthesia ${ }^{1}$ and in anaesthetized patients who are ventilated with intermittent positive pressure ventilation (IPPV), ${ }^{2,3}$ Rapid shallow ventilation (RSV) in which end-expiratory pressure remains slightly above zero may prevent this reduction. ${ }^{4,5}$ Jonzon et al. ${ }^{5}$ used high frequency ventilation in animals to promote stable cardiovascular conditions and Heijman, et al..$^{4}$ used it for surgical patients.

Stone and Sullivan, ${ }^{6}$ however, found a significant increase in the alveolar to arterial oxygen tension gradient $\left(\mathrm{AaDO}_{2}\right)$ in dogs during high frequency ventilation, but in their studies carbon dioxide tensions $\left(\mathrm{PaCO}_{2}\right)$ were lower than those found in normal awake beagles in our own laboratory ${ }^{7}$ and that of Feigl and D'Alecy. ${ }^{8}$ Low $\mathrm{PaCO}_{2}$ may cause a fall in cardiac output ${ }^{9}$ and a rise in oxygen consumption $\left(\mathrm{VO}_{2}\right)^{10}$ both of which might be expected to increase $\mathrm{AaDO}_{2}$. Pichotka et al. ${ }^{11}$ found an increase in $\mathrm{AaDO}_{2}$ at a constant level of lowered alveolar $\mathrm{CO}_{2}$ tension $\left(\mathrm{PA}_{\mathrm{CO}_{2}}\right)$ and suggested that the $\mathrm{AaDO}_{2}$ is mainly determined by $\left.\mathrm{PA}_{(\cdot)}\right)_{2}$. Low regional $\mathrm{PA}_{\mathrm{C}^{\prime}()_{2}}$ has also been associated with regional hypoventilation, decreased compliance and increased veno-arterial shunting. ${ }^{12}$

We therefore compared the effect of rapid shallow ventilation at a constant minute ventilation (VE) on arterial oxygenation in dogs maintained at normal and low $\mathrm{PaCO}_{2}$ values for one to two hours. In some of the dogs we also compared FRC early and late during the period of artificial ventilation.

\section{METHODS}

Dogs were anaesthetized with intravenous pentobarbitone $(30 \mathrm{mg} / \mathrm{Kg})$, intubated with a cuffed tracheal tube and ventilated with air at a rate of $60-80$ /

'From the Department of Anaesthesia and the Intensive Care Unit, The Hospital for Sick Children, Toronto, and the Department of Anaesthesia, University of Toronto, Toronto, Ontario, Canada.

Supported by the Canariian Medical Research Council (Grant M.A. 3961). Certain equipment used in the study was purchased with funds made avajlable in 1971 by the Canadian Red Cross Youth, Ontario.

Reprint requests to Dr. Nisbet, Department of Anaesthesia, The Hospital for Sick Children, 555 University Avenue, Toronto, Ontario M5G 1X8.

Canad. Anaesth. Soc. J., vol. 21, no. 2, March 1974 
TABLE I

Rapid Shallow Ventilation

$\mathrm{PaO}_{2}$ and $\mathrm{AaDO}_{2}(\mathrm{~mm} \mathrm{Hg})$

(Mean and standard deviation)

\begin{tabular}{|c|c|c|c|c|c|c|c|}
\hline & \multicolumn{3}{|c|}{ Normal $\mathrm{PaCO}_{2}$} & \multicolumn{3}{|c|}{ Low $\mathrm{PaCO}_{2}$} & \\
\hline & Early & Late & Difference & Early & Late & Difference & \\
\hline $\mathrm{PaCO}_{2}$ & $\begin{array}{r}38 \\
3\end{array}$ & $\begin{array}{r}38 \\
4\end{array}$ & 0 & $\begin{array}{r}26 \\
2\end{array}$ & $\begin{array}{r}24 \\
3\end{array}$ & -2 & $\phi_{E} \phi_{\mathbf{L}}$ \\
\hline $\mathrm{PaO}_{2}$ & $\begin{array}{r}88 \\
8\end{array}$ & $\begin{array}{r}91 \\
4\end{array}$ & +3 & $\begin{array}{l}88 \\
15\end{array}$ & $\begin{array}{l}78 \\
16\end{array}$ & $-10^{*}$ & $\phi_{L}$ \\
\hline $\mathrm{PAO}_{2}$ & $\begin{array}{r}102 \\
9\end{array}$ & $\begin{array}{r}102 \\
7\end{array}$ & 0 & $\begin{array}{r}117 \\
2\end{array}$ & $\begin{array}{r}119 \\
2\end{array}$ & +2 & $\phi_{E} \phi_{L}$ \\
\hline $\mathrm{AaDO}_{2}$ & $\begin{array}{r}12 \\
7\end{array}$ & $\begin{array}{r}11 \\
6\end{array}$ & -1 & $\begin{array}{l}29 \\
14\end{array}$ & $\begin{array}{l}41 \\
17\end{array}$ & $+12^{*}$ & $\phi_{E} \phi_{L}$ \\
\hline
\end{tabular}

*Significant change from early to late within group.

$\phi_{\mathrm{E}}, \phi_{\mathrm{L}}$ : Significant difference between normal and low $\mathrm{PaCO}_{2}$ groups, early and late respectively.

minute using the Volgyesi ventilator, ${ }^{13}$ which enabled us to measure FRC. ${ }^{14} \mathrm{~A}$ catheter was placed in the femoral artery to collect arterial blood. Values for $\mathrm{PaO}_{2,}, \mathrm{PaCO}_{2}$, and $\mathrm{pH}$ were measured and corrected for changes in the dog's temperature, which were minimized by placing the animal on a heated blanket. We measured volume and oxygen and carbon dioxide content of expired gas.

After $\mathrm{PaCO}_{2}$ had stabilized at low values in one group of five dogs, and at normal values in a second group of five dogs, control measurements of $\mathrm{PaO}_{2}$ and $\mathrm{PaCO}_{2}$ were made and expired gas was collected and analysed. $\dot{\mathrm{VO}}_{2}$ and carbon dioxide elimination $\left(\dot{\mathrm{V}}_{\mathrm{CO}_{2}}\right)$ were measured and respiratory exchange $(\mathrm{R})$ and $\mathrm{PA}_{10,}$ were calculated. FRC was then measured in four dogs of each group and rapid shallow ventilation was continued at the same $\mathrm{VE}$ and $\mathrm{PaCO}_{2}$ for one to two hours, when the measurements and calculations were repeated.

In each group differences between the early control and late values were calculated and their significance was assessed by the paired t-test. The significance of the difference between values in the two groups of dogs at normal and low $\mathrm{PaCO}_{2}$ levels was assessed by Student's t-test.

\section{RESULTS}

In the dogs ventilated at constant low $\mathrm{PaCO}_{2}$, mean values for $\mathrm{PaO}_{2}$ fell significantly during the period of rapid shallow ventilation. AaDO.2 increased significantly in these dogs and was significantly higher than in the dogs ventilated at normal $\mathrm{PaCO}_{2}$, both at the beginning and end of the period of ventilation. Significant differences between the dogs at normal $\mathrm{PaCO}_{2}$ and those at low $\mathrm{PaCO}_{2}$ were also observed in the values for $\mathrm{PaCO}_{2}, \mathrm{PaO}_{2} \cdot$ (late values only), $\mathrm{PA}_{\mathrm{O}_{2}}$ and $\mathrm{f}$ ( Tables I, II, III).

No large change in mean FRC was observed during rapid shallow ventilation, in either group. FRC remained high in both groups (Table III). 
TABLE Il

Rapid Shallow Ventilation

$\dot{\mathrm{V}}_{\mathrm{O}_{2}}$ and $\mathrm{R}$

(Mean and standard deviation)

\begin{tabular}{|c|c|c|c|c|c|c|}
\hline & \multicolumn{3}{|c|}{ Normal $\mathrm{PaCO}_{2}$} & \multicolumn{3}{|c|}{ Low $\mathrm{PaCO}_{2}$} \\
\hline & Early & Late & Difference & Early & Late & Difference \\
\hline$\dot{V}_{O_{2}}$ & $\begin{array}{l}48 \\
12\end{array}$ & $\begin{array}{l}51 \\
11\end{array}$ & +3 & $\begin{array}{l}55 \\
16\end{array}$ & $\begin{array}{l}55 \\
17\end{array}$ & 0 \\
\hline$\left.\dot{\mathrm{V}}_{\mathrm{O}_{2}} \mathrm{ml} / \mathrm{Kg} \mathrm{STPD}\right)$ & $\begin{array}{l}4.00 \\
0.70\end{array}$ & $\begin{array}{l}4.24 \\
0.49\end{array}$ & +0.24 & $\begin{array}{l}5.68 \\
2.48\end{array}$ & $\begin{array}{l}5.68 \\
2.51\end{array}$ & $\begin{array}{l}0 \\
0\end{array}$ \\
\hline $\mathrm{R}$ & $\begin{array}{l}.83 \\
.17\end{array}$ & $\begin{array}{l}.82 \\
.18\end{array}$ & -0.02 & $\begin{array}{l}.83 \\
.08\end{array}$ & $\begin{array}{l}.80 \\
.11\end{array}$ & -0.03 \\
\hline
\end{tabular}

No significant changes.

TABLE III

Rapid Shallow Ventulation

Ventilation and FRC

(Mean and standard deviation)

\begin{tabular}{|c|c|c|c|c|c|c|c|}
\hline & \multicolumn{3}{|c|}{ Normal $\mathrm{PaCO}_{2}$} & \multicolumn{3}{|c|}{ Low $\mathrm{PaCO}_{2}$} & \\
\hline & Early & Late & Difference & Early & Late & Difference & \\
\hline$f(/ \min )$ & $\begin{array}{l}73 \\
1.2\end{array}$ & $\begin{array}{r}74 \\
1.9\end{array}$ & +1 & $\begin{array}{l}65 \\
1.3\end{array}$ & $\begin{array}{l}66 \\
2.5\end{array}$ & +1 & $\phi_{E} \phi_{L}$ \\
\hline $\begin{array}{l}\mathrm{VT} \\
\text { (ml ATPS) }\end{array}$ & $\begin{array}{l}70 \\
16.2\end{array}$ & $\begin{array}{l}69 \\
14.1\end{array}$ & -1 & $\begin{array}{l}85 \\
11.4\end{array}$ & $\begin{array}{l}84 \\
10.0\end{array}$ & -1 & \\
\hline $\begin{array}{l}\text { FRC } \\
\text { (ml BTPS) }\end{array}$ & $\begin{array}{r}632 \\
38\end{array}$ & $\begin{array}{r}621 \\
43\end{array}$ & -11 & $\begin{array}{l}457 \\
173\end{array}$ & $\begin{array}{l}527 \\
216\end{array}$ & +70 & \\
\hline $\begin{array}{l}\text { FRC } \\
(\mathrm{ml} / \mathrm{Kg} \text { BTPS })\end{array}$ & 50 & $\begin{array}{r}49 \\
4\end{array}$ & -1 & $\begin{array}{l}47 \\
12\end{array}$ & $\begin{array}{l}54 \\
18\end{array}$ & +7 & \\
\hline
\end{tabular}

$\phi_{\mathrm{E}}, \phi_{\mathrm{L}}$ : Significant difference between normal and low $\mathrm{PaCO}_{2}$ groups, early and late respectively.

\section{Discussion}

The principal differences between the two groups of dogs is a fall in $\mathrm{PaO}_{2}$ which occurred in spite of a rise in $\mathrm{PAO}_{2}$ in the hyperventilated dogs. A similar fall in $\mathrm{PaO}_{2}$ and an increase in the $\mathrm{AaDO}_{2}$ gradient has been reported during hyperventilation at a constant low $\mathrm{PaCO}_{2}$ by Pichotka et al. ${ }^{11}$ Stone and Sullivan ${ }^{6}$ also noted increasing $\mathrm{AaDO}_{2}$ in dogs ventilated rapidly at $\mathrm{PaCO}_{2}$ values lower than those measured in normal conscious dogs. ${ }^{7,8}$ This increase in $\mathrm{AaDO}_{2}$ was not due to increased true shunt but could be associated with a fall in cardiac output (Q) or increased $\dot{\mathrm{VO}}_{2}$ or an increased maldistribution of ventilation in relation to perfusion.

The use of gas exchange equations at a tidal volume lower than deadspace volume may lead to error. ${ }^{15}$ The tidal volumes in the present study are sufficiently above deadspace volume to give reasonable values for $\mathrm{R}$ and $\mathrm{PAO}_{2}$.

In our studies the raised $\mathrm{PA}_{\mathrm{O}_{2}}$ resulting from hyperventilation was not paralleled by an increase in $\mathrm{PaO}_{2}$. Khambatta and Sullivan ${ }^{16}$ also report that in dogs hyperventilated with air, $\mathrm{PaO}_{2}$ does not rise as much as expected.

We were unable to differentiate between the effects of changes in cardiac 
output, shunt, or venous admixture. Although $\dot{\mathrm{VO}}_{2}$ was higher in hyperventilated dogs the difference between the two groups of dogs was not significant and the values for $\dot{\mathrm{VO}}_{2}$ remained constant throughout the hyperventilation. It seems likely, therefore, that falls in cardiac output, or increasingly inappropriate distribution of ventilation in relation to perfusion, or both, were responsible for the decrease in arterial oxygenation. Low $\mathrm{CO}_{2}$ levels in alveolar and bronchial gas may also have caused regional hypoventilation. ${ }^{12}$

The important consideration is that when $\mathrm{PaCO}_{2}$ was normal no decrease in arterial oxygen tension or increase in $\mathrm{AaDO}_{2}$ occurred during rapid shallow ventilation over the period studied. $\mathrm{PaO}_{2}$ remained close to the average value for conscious dogs breathing air ${ }^{8}$ and during both the early and late measurements $\mathrm{AaDO}_{2}$ was below the values measured by others in anaesthetized ventilated dogs. ${ }^{17}$ If we insert the blood gas values measured in these dogs at normal $\mathrm{PaCO}_{2}$ into the ventilation shunt grid of Owen-Thomas ${ }^{18}$ the amount of venous admixture is in the region of 5 per cent of cardiac output, which is less than that usually measured in anaesthetized dogs $s^{16,21}$ or humans. ${ }^{22}$

The mean values for $\mathrm{FRC}$ which we measured during rapid shallow ventilation $\left(52.0 \mathrm{ml} / \mathrm{Kg}\right.$ and $47.0 \mathrm{ml} / \mathrm{Kg}$ in the normal and low $\mathrm{PaCO}_{2}$ groups respectively) are considerably higher than those in conscious, prone dogs $(40.3 \mathrm{ml} / \mathrm{Kg}$ at mean $\mathrm{PaCO}_{2}$ of $36 \mathrm{~mm} \mathrm{Hg}{ }^{19}$ and those for anaesthetized dogs breathing spontaneously $(26.7 \mathrm{ml} / \mathrm{Kg}) .{ }^{20}$

We conclude that over a period of 1 to 2 hours rapid shallow ventilation with air is able to maintain FRC at values slightly above those in conscious dogs and that if $\mathrm{PaCO}_{2}$ is kept within normal limits, no fall in $\mathrm{PaO}_{2}$ or increase in $\mathrm{AaDO}_{2}$ will occur. This pattern of artificial ventilation may, therefore, be useful in preventing the falls in FRC and increases in venous admixture described with other techniques of artificial ventilation in anaesthetized subjects.

\section{RÉSUMÉ}

La capacité fonctionnelle résiduelle est diminuée durant l'anesthésie et chez les patients ventilés avec pression positive intermittente. ${ }^{2.3}$ Une ventilation rapide et superficielle avec maintien d'une pression légèrement positive en fin d'expiration peut prévenir cette réduction. ${ }^{4.5}$

Nous avons étudié les effets d'une ventilation rapide et superficielle chez deux groupes de chiens. Le premier groupe de chien a été hyperventilé, la $\mathrm{PaCO}_{2}$ étant maintenu basse de façon constante; les valeurs moyennes de la $\mathrm{PaO}_{2}$ diminuèrent de façon significative durant le ventilation rapide et superficielle. Le second groupe fut ventilé de façon à maintenir le $\mathrm{PaCO}_{2}$ à des chiffres normaux.

Les capacités fonctionnelles résiduelles ont été mesurées durant les périodes de ventilation superficielle et rapide et les chiffres moyens obtenus montrent une augmentation considérable par rapport à ceux que l'on retrouve chez les chiens conscients en position couchée et par comparaison avec ceux trouvés chez les chiens anesthésiés et respirant spontanément. 
Nous concluons qu'une période d'une à deux heures de ventilation rapide et superficielle avec de l'air peut maintenir des capacités résiduelles fonctionnelles légèrement supérieures à celles trouvées chez des chiens conscients et nous concluons de plus que si les $\mathrm{PaCO}_{2}$ sont maintenues normales il n'y aura pas de chute de la $\mathrm{PaO}_{2}$ et le gradient alvéolo-capillaire n'augmentera pas. Ce genre de ventilation peut donc ètre utile pour prévenir des chutes de la capacité fonctionelle résiduelle et les augmentations du shunt décrites avec les autres techniques de ventilation artificielle chez les malades anesthésiés.

\section{ACKNOWLEDGMENTS}

We are grateful for the assistance of Dr. J. Mahmoud, Mrs. Lisa Joyal, the Department of Medical Publications, Hospital for Sick Children, and Miss Sandra Mitchell. We also thank Dr. A.C. Bryan for his advice concerning the presentation of the data.

\section{REFERENCES}

1. Don, H.F., Wahba, M., Cuadrado, L., \& Kelkan, K. The effects of anesthesia and 100 per cent oxygen on the functional residual capacity of the lungs. Anesthesiology 32: 521 (1970).

2. LAws, A.K. Effects of induction of anaesthesia and muscle paralysis on functional residual capacity of the lungs. Can. Anaesth. Soc. J. 15: 325 (1968).

3. Dobrinson, T.L., Nisbet, H.I.A., Pelton, D.A., \& Levison, H. Functional residual capacity (FRC) and compliance in anaesthetized paralyzed children. Part II. Clinical results. Can. Anaesth. Soc. J. 20:322 (1973).

4. Heijman, K., Heijman, L., Jonzon, A., Sedin, G., Sjöstrand, U., \& Widman, B. High frequency positive pressure ventilation during anaesthesia and routine surgery in man. Acta Anaes. Scand, 16: 176 (1972).

5. Jonzon, A., Öberg, P.A., SEdin, G., \& SJöstrand, U. High-frequency positive-pressure ventilation by endotracheal insufflation. Acta. Anaes. Scand. suppl. 43 (1971).

6. Stone, J.G. \& Sulltvan, S.F. Failure of shallow ventilation to produce pulmonary shunting in the anesthetized dog. Anesthesiology 32: 338 (1970).

7. Love, J. Personal communication.

8. Feigl, E.O. \& D'Alecy, L.G. Normal arterial blood $\mathrm{pH}$, oxygen and carbon dioxide tensions in unanesthetized dogs. J. Appl. Physiol. 32: 152 (1972).

9. Prys-Roberts, C., Kelman, G.R., Greenbaum, R., Kain, M.L., \& Bay, J. Hemodymamics and alveolar-arterial $\mathrm{PO}_{2}$ differences at varying $\mathrm{PacO}_{2}$ in anaesthetized man. J. Appl. Physiol. 25: 80 (1968).

10. KARETZKY, M.S. \& CAIN, S.M. Effect of carbon dioxide on oxygen uptake during hyperventilation in normal man. J. Appl. Physiol. 28: 8 (1970).

11. Pichotka, J.P., Krekeler, H., Schotte, J., \& Muysers, K. Changes of the alveolararterial $\mathrm{O}_{2}$-pressure-difference during hyperventilation. Pflügers Arch. 327: 53 (1971).

12. Michenfelder, J.D., Fowler, W.S., \& THEye, R.A. $\mathrm{CO}_{2}$ levels and pulmonary shunting in anesthetized man. J. Appl. Physiol. $21: 1471$ (1966).

13. Volgyesi, G. \& Nisbet, H.I.A. A new piston ventilator for use in respiratory studies. Can. Anaesth. Soc. J. 19: 662 (1972).

14. Dobeinson, T.L., Nisbet, H.I.A., \& Pelton, D.A. Functional residual capacity (FRC) and compliance in anaesthetized paralysed children. Part I. In vitro tests with the helium dilution method of measuring FRC. Can. Anaesth. Soc. J. 20: 310 (1973).

15. Briscoe, W.A., Fonster, R.E., \& Comroe, J.H., Jr. Alveolar ventilation at very low tidal volumes. J. Appl. Physiol. 7: 27 (1954).

16 Khambatta, H.J. \& Sullivan, S.F. Effects of respiratory alkalosis on oxygen consumption and oxygenation. Anesthesiology 38: 53 (1973). 
17. Schuuhians Stekhoven, J.H. \& Kreuzer, F. Alveolar-arterial $\mathrm{O}_{2}$ and $\mathrm{CO}_{2}$ pressure differences in the anesthetized, artificially ventilated dog. Resp. Physiol, 3: 177 (1967).

18. Owen-Thomas, J.B. Care of the critically ill child. Eds. R.S. Jones \& J.B. Owen-Thomas. London. Edward Arnold (Pub.) Ltd., p. 50 (1971).

19. Pickrell, J.A., Dubin, S.E., \& Elliott, J.C. Normal respiratory parameters of unanesthetized beagle dogs. Lab. Anim. Sci. 21: 677 (1971).

20. Mead, J. \& Collier, C. Relation of volume history of lungs to respiratory mechanics in anesthetized dogs. J. Appl. Physiol. 14: 669 (1959).

21. Collier, C. \& MEad, J. Pulmonary exchange as related to altered pulmonary mechanics in anesthetized dogs. J. Appl. Physiol. 19: 659 (1964).

22. Nunn, J.F., Bergman, N.A., \& Coleman, A.J. Factors influencing the arterial oxygen tension during anaesthesia with artificial ventilation. Br. J. Anaesth. 37: 898 (1965). 